\title{
Growth of red and green strains of the tropical agarophyte Gracilaria cornea J.Agardh (Gracilariales, Rhodophyta) in laboratory
}

\author{
LUCIANA B. FERREIRA ${ }^{1}$, JOSÉ B. BARUFI ${ }^{1}$ and ESTELA M. PLASTINO ${ }^{1,2}$
}

(received: March 24, 2005; accepted: February 16, 2006

\begin{abstract}
Growth of red and green strains of the tropical agarophyte Gracilaria cornea J. Agardh (Gracilariales, Rhodophyta) in laboratory). Gracilaria cornea J. Agardh is an important agarophyte occurring in the western Atlantic Ocean. Green colour individuals of G. cornea were found in a natural population, growing next to red individuals, which were more common. Due to the importance of colour strains in genetic and intraspecific variability studies, this work aimed to characterize the red and green strains evaluating different nutritional and light conditions. Red and green gametophytes were cultivated at 14:10 light: dark cycle, with alternating aeration periods of $30 \mathrm{~min}$. Two different enriched solutions were tested: von Stosch (VSS) at concentrations reduced to $12.5 \%$ and $25 \%$; and Provasoli (PES) at concentrations reduced to $25 \%$ and $50 \%$, and $100 \%$. Red and green gametophytes were cultivated at the irradiance of $45 \mu \mathrm{mol}$ photons $\mathrm{m}^{-2} \mathrm{~s}^{-1}$. In another experiment utilizing PES $100 \%$, two sources of light (Osram $40 \mathrm{~W}$ daylight fluorescent tubes and Sylvania Designer 3,500 tubes) were tested at irradiances of 90 and $180 \mu \mathrm{mol}$ photons $\mathrm{m}^{-2} \mathrm{~s}^{-1}$. Growth rates (GR) were evaluated for five weeks. Gametophytes developed few branches and reproductive structures were not induced. Differences were not observed between GR of red and green strains in the conditions tested. GR were higher in VSS $12.5 \%\left(8.4 \%\right.$ day $\left.^{-1}\right)$ than in $25 \%\left(7.1 \%\right.$ day $\left.^{-1}\right)$, suggesting an adaptation of the species to low nutrient concentrations. GR were higher at $180\left(9.0 \%\right.$ day $\left.^{-1}\right)$ than at $90 \mu \mathrm{mol}$ photons $\mathrm{m}^{-2} \mathrm{~s}^{-1}\left(6.3 \%\right.$ day $\left.^{-1}\right)$. These results suggest that $G$. cornea should be cultivated in laboratory at high irradiances and low nutrient concentrations. These data will be useful in future genetic and physiological studies of the species.
\end{abstract}

Key words - agarophyte, colour strain, Gracilaria cornea, growth, light

RESUMO - (Crescimento de linhagens de coloração verde e vermelha da agarófita tropical Gracilaria cornea J. Agardh (Gracilariales, Rhodophyta) em laboratório). Gracilaria cornea J. Agardh é uma importante agarófita que ocorre no Oeste do Oceano Atlântico. Indivíduos de coloração verde de G. cornea foram encontrados em uma população natural, próximos a indivíduos de coloração vermelha, mais comuns. Devido à importância de linhagens cromáticas em estudos de genética e variabilidade intraespecífica, o objetivo deste trabalho foi caracterizar as linhagens verde e vermelha avaliando diferentes condições de nutrintes e luz. Gametófitos verdes e vermelhos foram cultivados em fotoperíodo de 14 horas (14L:10E), com períodos alternados de aeração de 30 minutos. Duas soluções de água do mar enriquecida foram testadas: von Stosch (VSS) nas concentrações reduzidas a 12,5\% e 25\%; e Provasoli (PES) nas concentrações reduzidas de $25 \%$ e $50 \%$, e $100 \%$. A irradiância foi de $45 \mu \mathrm{mol}$ fótons $\mathrm{m}^{-2} \mathrm{~s}^{-1}$. Num outro experimento, utilizando-se PES $100 \%$, dois tipos de fontes luminosas (lâmpadas fluorescentes Osram $40 \mathrm{~W}$ luz do dia e Sylvania Designer 3.500) foram testadas em duas irradiâncias: 90 e $180 \mu \mathrm{mol}$ fótons $\mathrm{m}^{-2} \mathrm{~s}^{-1}$. As taxas de crescimento (TC) foram avaliadas durante cinco semanas. Todas as condições testadas não promoveram a diferenciação de estruturas reprodutivas e poucas ramificações foram formadas nos gametófitos vermelhos e verdes. As linhagens selvagem e verde apresentaram TC semelhantes, que foram maiores em VSS $12,5 \%\left(8,4 \%\right.$ dia $\left.^{-1}\right)$ do que em VSS 25\% (7,1\% dia $\left.^{-1}\right)$, sugerindo uma adaptação da espécie a baixas concentrações de nutrientes. As taxas de crescimento foram maiores em $180\left(9,0 \% \mathrm{dia}^{-1}\right)$ do que em $90 \mu \mathrm{mol}$ fótons $\mathrm{m}^{-2} \mathrm{~s}^{-1}\left(6,3 \% \mathrm{dia}^{-1}\right)$. Sugere-se que G. cornea seja cultivada em altas irradiâncias e baixas concentrações de nutrientes. Esses resultados devem ser considerados em futuros estudos genéticos e fisiológicos da espécie.

Palavras-chave - agarófita, crescimento, Gracilaria cornea, linhagens cromáticas, luz

\section{Introduction}

The genus Gracilaria Greville (Gracilariales, Rhodophyta) is responsible for more than $50 \%$ of the agar production in the world (McHugh 1991). Although

\footnotetext{
1. Universidade de São Paulo, Instituto de Biociências, Caixa Postal 11461, 05422-970 São Paulo, SP, Brasil.

2._Corresponding author: emplasti@usp.br
}

there are many studies concerning the physiology of the genus, few of them focus on colour strains. Colour mutants have been observed in many species of Gracilaria (Zhang \& van der Meer 1988, Levy \& Friedlander 1990, van der Meer 1990, Plastino et al. 1999), most of them are green (van der Meer 1990). Some colour strains occur spontaneously (van der Meer 1990, Plastino et al. 1999, Costa \& Plastino 2001, Plastino et al. 2004), while others are artificially produced in laboratory (van der Meer 1990). Colour 
strains have been used as tools in studies investigating algal life histories, photosynthesis, morphology, genetics and reproduction (van der Meer 1981, 1986).

Gracilaria cornea J. Agardh is distributed in the western Atlantic Ocean from Bermuda, through the Gulf of Mexico to Cabo Frio, Brazil (Bird et al. 1986). Along with G. birdiae Plastino \& E.C. Oliveira, it is the main species utilized for agar production in Brazil (Plastino \& Oliveira 2002). Moreover, G. cornea has been considered an important option for aquaculture in Mexico (Orduña-Rojas \& Robledo 2002). The agar yield and quality have shown the potentiality of this species for colloid industry (Leon 1990, Freile-Pelegrín et al. 2002). As a consequence of this economic importance, many aspects of G. cornea physiology have been studied, such as translocation of photosynthates (Gonen et al. 1996), growth under laboratory conditions (Yokoya \& Oliveira 1992, Navarro-Angulo \& Robledo 1999), photosynthesis and pigments (Dawes et al. 1999), UV-absorbing compounds (Sinha et al. 2000), agar quality (Leon 1990, Freile-Pelegrín et al. 2002, Espinoza-Avalos et al. 2003) and reproduction (Guzmán-Urióstegui \& Robledo 1999, Orduña-Rojas \& Robledo 2002). However, none of these studies focused on colour strains.

Green individuals of Gracilaria cornea were found in a natural population from Ceará State, Brazil, growing next to red individuals, which were more commonly found. Differently from other "gracilarioid algae", attempts to cultivate G. cornea in laboratory have been a hard task (Plastino 2004). Due to the commercial value of this species, as well as the importance of colour strains in genetic and intraspecific variability studies, this study aimed to characterize the red and green strains evaluating growth rates at different nutritional and light conditions.

\section{Material and methods}

Apical segments of red and green gametophytes of Gracilaria cornea J. Agardh were obtained from the germination of tetraspores released from tetrasporophytic branches collected on Meireles Beach ( $3^{\circ} 32^{\prime} \mathrm{S}$ and $41^{\circ} 42^{\prime} \mathrm{W}$ ), Fortaleza, Ceará State, Brazil.

Non-axenic unialgal cultures were established as described by Plastino \& Oliveira (1990). Standard culture conditions were: $14-10 \mathrm{~h}$ light-dark cycle, alternating aeration periods of 30 minutes, $25 \pm 1{ }^{\circ} \mathrm{C}$, sterile seawater (32 psu) enriched with von Stosch solution, VSS (Edwards 1970, modified by Plastino 1985) or Provasoli solution, PES (McLachlan 1973) without the buffer tris(hydroxymethyl)aminomethane (table 1). This enriched
Table 1. Chemical composition of von Stosch (Edwards 1970, modified by Plastino 1985) and Provasoli (Mc Lachlan 1973) culture media. (I) tris(hydroxymethyl)aminomethane. $\mathrm{pH}$ was adjusted to 7.8 with $5 \mathrm{~N} \mathrm{HCl}$. (II) Ethylenediaminetetraacetic acid.

\begin{tabular}{lrr}
\hline Aditive & von Stosch & Provasoli \\
\hline $\mathrm{NaNO}_{3}$ & $0.50 \mathrm{mM}$ & $0.66 \mu \mathrm{M}$ \\
$\mathrm{Na}_{2}$-glycerophosphate. $5 \mathrm{H}_{2} \mathrm{O}$ & - & $25.00 \mu \mathrm{M}$ \\
$\mathrm{Na}_{2} \mathrm{HPO}_{4} \cdot 12 \mathrm{H}_{2} \mathrm{O}$ & $30.00 \mu \mathrm{M}$ & - \\
$\mathrm{MnSO}_{4} \cdot \mathrm{H}_{2} \mathrm{O}$ & $0.10 \mu \mathrm{M}$ & $7.30 \mu \mathrm{M}$ \\
$\mathrm{FeCl}_{3} \cdot 6 \mathrm{H}_{2} \mathrm{O}$ & $1.15 \mu \mathrm{M}$ & $1.80 \mu \mathrm{M}$ \\
$\mathrm{Fe} \mathrm{EDTA}_{3}$ & - & $7.20 \mu \mathrm{M}$ \\
$\mathrm{H}_{3} \mathrm{BO}_{3}$ & - & $185.00 \mu \mathrm{M}$ \\
$\mathrm{ZnSO}_{4} \cdot 7 \mathrm{H}_{2} \mathrm{O}$ & - & $0.80 \mu \mathrm{M}$ \\
$\mathrm{CoSO}_{4} .7 \mathrm{H}_{2} \mathrm{O}$ & - & $0.17 \mu \mathrm{M}$ \\
Thiamine $_{\text {Biotin }}$ & $0.59 \mu \mathrm{M}$ & $0.06 \mu \mathrm{M}$ \\
Cyanocobalamin & $4.10 \mathrm{nM}$ & $3.57 \mathrm{nM}$ \\
Tris (I) & $0.74 \mathrm{nM}$ & $1.18 \mathrm{nM}$ \\
EDTA(II) & - & $0.66 \mathrm{mM}$ \\
\end{tabular}

seawater was changed weekly. Irradiance was measured with a Li-COR laboratory quantum scalar irradiance meter (mod. LI-185) connected to a Li-COR spherical quantum sensor considering photosynthetically active radiation (model Li-193). Different values of irradiance were used according to the experiment.

Apical segments were distributed into $400 \mathrm{~mL}$ conical flasks. Three replicates of green and three of red branches from different individuals were utilized for each experimental condition. Replicates consisted of two or three apical segments, with $1 \mathrm{~cm}$ and $3 \mathrm{mg}$ each. Branches were acclimated to the experimental conditions for two weeks. Fresh biomass was measured with an analytical balance once a week for five weeks. As growth was constant during the experimental period, growth rates were calculated (Lignell \& Pedersén 1989) using the last and the first measurements of fresh weight.

Two different enriched solutions were tested: VSS diluted to $12.5 \%$ and $25 \%$; and PES diluted to $25 \%, 50 \%$, and $100 \%$. The irradiance utilized was $45 \mu \mathrm{mol}$ photons $\mathrm{m}^{-2} \mathrm{~s}^{-1}$, provided by Osram $40 \mathrm{~W}$ daylight fluorescent tubes.

Two sources of light were tested: Osram $40 \mathrm{~W}$ daylight fluorescent tubes and Sylvania Designer 3,500 tubes. The radiation spectra of the models of these two lamps are showed on figure 1. Two different irradiances were tested for each kind of lamp: 90 and $180 \mu \mathrm{mol}$ photons $\mathrm{m}^{-2} \mathrm{~s}^{-1}$. Branches were cultivated in sterile seawater enriched with PES $100 \%$.

Since the data presented normal distribution and there was homocedasticity, an analysis of variance could be performed. Growth rates were analysed by a two-way ANOVA (independent variables: strain and enriched solution) for 

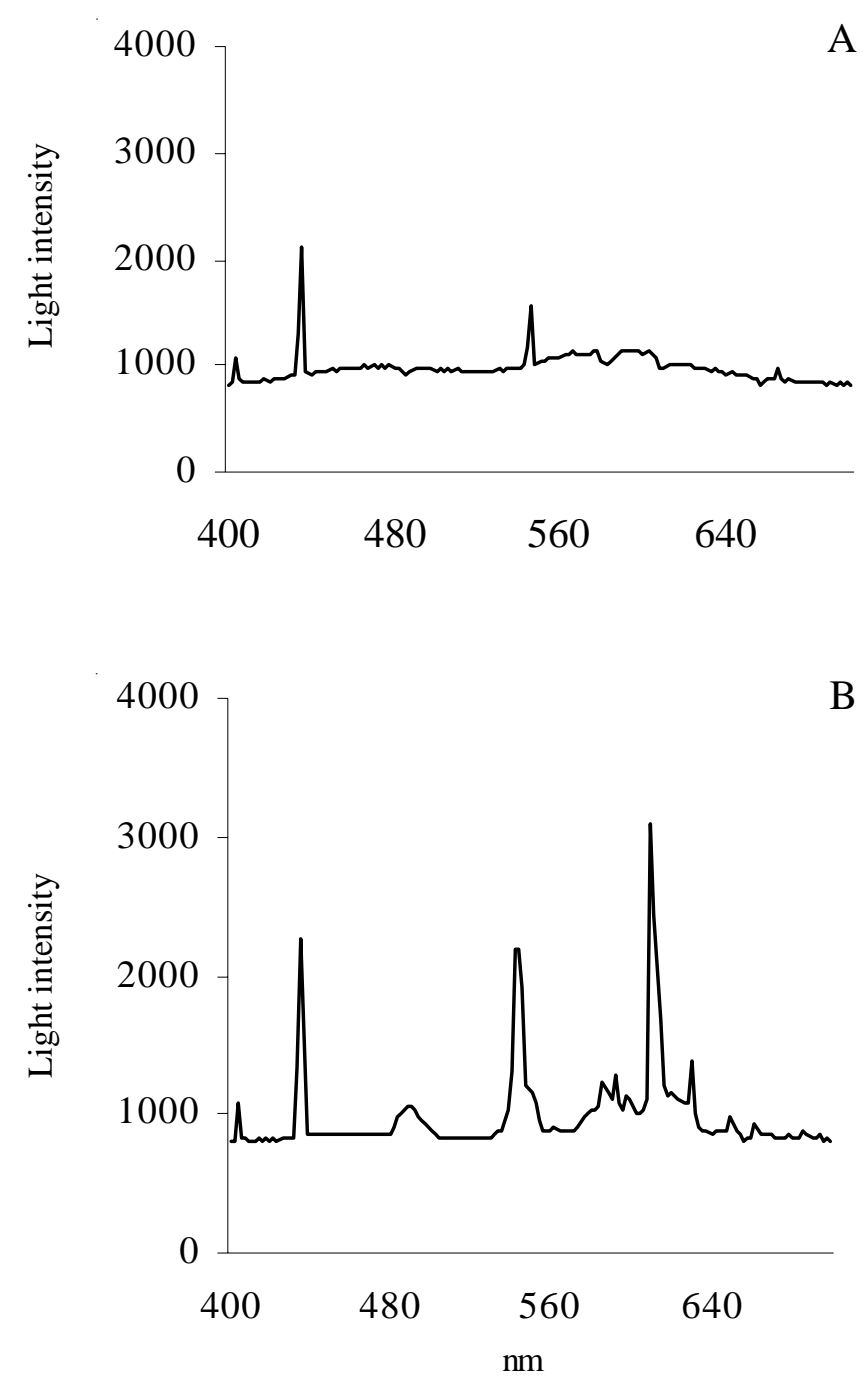

Figure 1. Radiance spectra of the sources of light. A. Osram 40W day light tube. B. Sylvania Designer 3,500 tube.

experiment of enriched solutions and a three-way ANOVA (independent variables: strain, irradiance, and light quality) for experiment of light. A Newman-Keuls post-hoc test was performed when necessary.

\section{Results}

There was an increase in mass of the branches in all of the conditions tested along the experimental period. Apical segments exhibited a reddish colour at the beginning of the experiments, regardless of being originated from red or green gametophytes. After four weeks at the experimental conditions, however, branches of green gametophytes already showed a greenish colour, although the tips of all the branches still had a reddish colour. Few ramifications were observed during the experimental period. None of the conditions tested induced the differentiation of reproductive structures.

Green and red strains showed similar growth rates, both when cultivated in VSS $(d f=1 ; F=0.131$; $P=0.726)$ or in PES $(d f=1 ; F=1.496 ; P=0.245)$. Branches cultivated in VSS $12.5 \%$ had higher growth rates than those cultivated in VSS $25 \%(d f=1$; $F=6.228 ; P=0.037$ ) (figure $2 \mathrm{~A}$ ). Branches cultivated in PES showed similar growth rates in all concentrations tested ( $d f=2 ; F=0.153 ; P=0.856$ ) (figure 2B).

Green and red strains had similar growth rates in each of the conditions tested for irradiance and sources of light ( $d f=1 ; F=0.371 ; P=0.551)$. The only factor which affected growth rates was irradiance $(d f=1$; $F=69.821 ; P=0.000)$. Higher growth rates were observed at the irradiance of $180 \mu$ mol photons $\mathrm{m}^{-2} \mathrm{~s}^{-1}$. Branches showed similar growth rates when cultivated under both light sources $(d f=1 ; F=0.404 ; P=0.534)$ (figure 3).
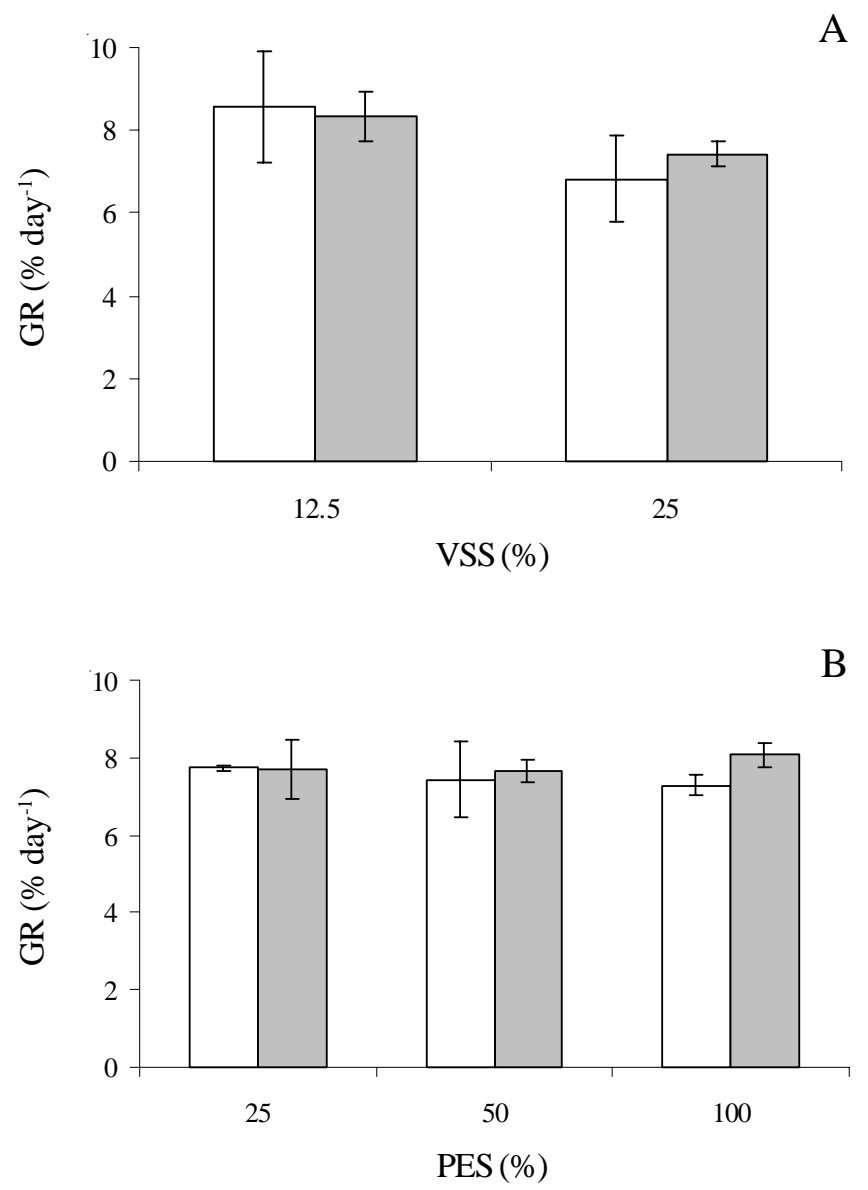

Figure 2. Growth of green and red gametophytes of Gracilaria cornea J. Agardh in different enriched seawater solutions (VSS $12.5 \%$ and 25\%; PES 25\%, 50\%, and $100 \%$ ). $\mathrm{GR}=$ growth rates $\left(\%\right.$ day $\left.{ }^{-1}\right)$. A. von Stosch solution. B. Provasoli solution. $(\square=$ green; $\square=$ red $)$. 

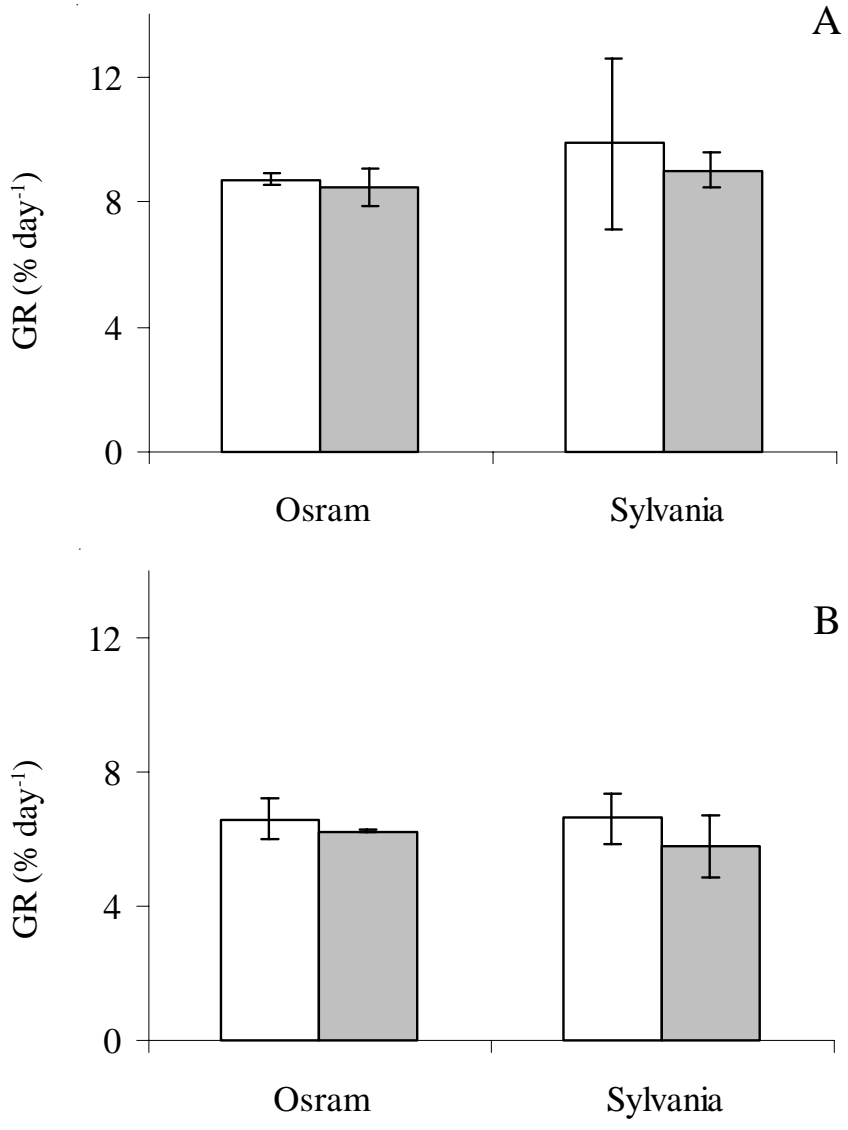

Sources of light

Figure 3. Growth of green and red gametophytes of Gracilaria cornea J. Agardh under different light sources (Osram $40 \mathrm{~W}$ daylight fluorescent tubes and Sylvania Designer 3500 tubes) and irradiances. $\mathrm{GR}=$ growth rates $\left(\%\right.$ day $\left.^{-1}\right)$. A. $180 \mu \mathrm{mol}$ photons $\mathrm{m}^{-2} \mathrm{~s}^{-1}$. B. $90 \mu \mathrm{mol}$ photons $\mathrm{m}^{-2} \mathrm{~s}^{-1}$. ( $\square=$ green; $\square=$ red $)$.

\section{Discussion}

The reddish colour of the tips of green specimens of Gracilaria cornea indicates that the green phenotype is expressed only in more mature thalli, as observed in G. domingensis Sonder ex Kützing (Plastino et al. 1999) and G. tikvahiae McLachlan (van der Meer \& Bird 1977). Probably in young cells the volume occupied by chloroplasts is large when compared to the small size of vacuoles and the whole cells, which can mask the green colour, expressed only when chloroplasts are more disperse in the mature cells.

Although there are some studies concerning the growth of G. cornea, it is difficult to make comparative analysis among them, since they were performed in different culture conditions and the formula used to calculate growth rates also varied. When growth rates were simultaneously compared to other species of the genus in laboratory, G. cornea showed small growth (Yokoya \& Oliveira 1992). Growth rates seem to be low also for plants of the species cultivated in the field (Leon 1990). When the same formula used in this study was applied to calculate growth rates for plants utilized by that author, the average growth rates obtained were similar to the ones observed in the present work $\left(8.3 \%\right.$ day $^{-1} \times 7.7 \%$ day $^{-1}$, respectively). The few branches presently observed also corroborate those data.

The higher growth rates observed when $G$. cornea was cultivated in VSS $12.5 \%$ may suggest an adaptation of the species to low nutrient concentrations, which is common in tropical oligotrophic waters. Most enriched solutions of seawater are developed for algae from temperate regions (McLachlan 1973); for this reason, a dilution may become necessary to cultivate tropical species such as G. cornea. Indeed, a detrimental effect of high phosphate concentrations had already been reported for the species (Navarro-Angulo \& Robledo 1999). Deleterious effects on growth were also observed for Kappaphycus alvarezii (Doty) Doty ex P. Silva, when it was cultivated at PES $100 \%$ or $50 \%$ (Paula et al. 2001). These effects were attributed to the high nutrient concentrations, although the presence of the buffer tris(hydroxymethyl)aminomethane also contributed to the decrease in growth rates. This buffer was not used in the present work.

The effect of dilution on growth rates of Gracilaria cornea was observed for VSS, but not for PES. Although both enriched solutions have some components in common, they are found in different concentrations (table 1). Furthermore, the phosphorus source in VSS is inorganic $\left(\mathrm{Na}_{2} \mathrm{HPO}_{4} .12 \mathrm{H}_{2} \mathrm{O}\right)$, while in PES it is organic $\left(\mathrm{Na}_{2}\right.$-glycerophosphate. $\left.5 \mathrm{H}_{2} \mathrm{O}\right)$, which makes it possible to use this additive as a carbon source. Moreover, some nutrients are found only in PES, such as a trace metal solution (zinc, cobalt, iron and boron). These data suggest that the dilution effects of PES on growth rates were not observed because it is a reacher medium. It is expected that at lower PES concentrations higher growth rates will be observed.

Growth rates were higher when plants were cultivated at $180 \mu \mathrm{mol}$ photons $\mathrm{m}^{-2} \mathrm{~s}^{-1}$ than at $90 \mu \mathrm{mol}$ photons $\mathrm{m}^{-2} \mathrm{~s}^{-1}$. This result was expected, since G. cornea is a tropical species that is exposed to a much higher irradiance in its natural habitat. However, a saturation irradiance of $120 \mu \mathrm{mol}$ photons $\mathrm{m}^{-2} \mathrm{~s}^{-1}$ was obtained for plants of the species recently collected from natural populations (Orduña-Rojas et al. 2002). Although this parameter depends on the interaction of 
many factors, the lower irradiance tested in the present study is beyond this value, which helps to explain why growth rates were higher at the higher irradiance tested.

The light spectrum of Sylvania tubes showed emission peaks at $610 \mathrm{~nm}$ that is absent in Osram tubes and a stronger peak at $544 \mathrm{~nm}$. The pigments responsible for the absorption at these wavelengths are phycocyanin and phycoerythrin, respectively (Lobban \& Harrison 1997). It would be expected that red algae showed higher growth rates when cultivated under the first tube, as it could provide a better use of the energy transmitted by those wavelengths. Higher growth rates were observed for $G$. domingensis, when cultivated under Sylvania tubes in our laboratory (Guimarães 2000). Conversely, the growth rates of G. cornea were similar when it was cultivated under both kinds of tube.

The absence of reproductive structures during the experimental period could be a result of a possible excess of nutrients, although other factors might also affect reproduction, such as temperature, salinity, photoperiod or irradiance (Guiry 1984, Graham et al. 1985, Anderson \& Bolton 1989, Hoffmann \& Malbrán 1989). Gametophytes of $G$. cornea have been cultivated in our laboratory for several years and, up to now, they have not become fertile, differently from other "gracilarioid species" (Plastino \& Oliveira 1988a e b, Guimarães et al. 1999, Costa \& Plastino 2001).

Most colour variants investigated in Rhodophyta have shown a lower performance when compared to the wild types, probably because most of them are mutants produced artificially in laboratory (van der Meer 1990). In some cases, however, this performance was higher (Ramus \& van der Meer 1983, Dawes et al. 1994, Guimarães 2000). In the present study, green and red strains of Gracilaria cornea presented similar growth rates in all tested conditions, suggesting the potential of the green strain to be tested in mariculture experiments.

Acknowledgements - This project was supported by $\mathrm{CNPq}$ (proc. 300148/93-3 and 10321/98-6) and Fapesp (proc. 98/11943-1). We thank Rosario Petti for support during the experimental period and Helena Khouri and Maria Lucia Kawasaki for the English revision of the manuscript.

\section{References}

ANDERSON, R.J. \& BOLTON, J.J. 1989. Growth and fertility, in relation to temperature and photoperiod, in South African Desmarestia firma (Phaeophyceae). Botanica Marina 32:149-158.
BIRD, C.J., OLIVEIRA, E.C. \& MCLACHLAN, J. 1986. Gracilaria cornea, the correct name for the western Atlantic alga hitherto known as G. debilis (Rhodophyta, Gigartinales). Canadian Journal of Botany 64:2045-2051.

COSTA, V.L. \& PLASTINO, E.M. 2001. Histórico de vida de espécimens selvagens e variantes cromáticas de Gracilaria sp. (Gracilariales, Rhodophyta). Revista Brasileira de Botânica 24:491-500.

DAWES, C.J., LLUISMA, A.O. \& TRONO, G.C. 1994. Laboratory and field growth studies of commercial strains of Eucheuma denticulatum and Kappaphycus alvarezii in the Philippines. Journal of Applied Phycology 6:21-24.

DAWES, C.J., ORDUÑA-ROJAS, J. \& ROBLEDO, D. 1999. Response of the tropical red seaweed Gracilaria cornea to temperature, salinity and irradiance. Journal of Applied Phycology 10:419-425.

EDWARDS, P. 1970. Illustrated guide to the seaweeds and sea grasses in the vicinity of Porto Aransas, Texas. Contributions in Marine Science 15:1-228.

ESPINOZA-AVALOS, J.E., HERNÁNDEZ-GARIBAY, E., ZERTUCHE-GONZÁLEZ, J.A. \& CASTILLO, M.E.M. 2003. Agar from two coexisting species of Gracilaria (Gracilariaceae) from the Mexican Caribbean. Ciencias Marinas 29:211-218.

FREILE-PELEGRÍN, Y., ROBLEDO, D., PEDERSÉN, M., BRUNO, E. \& RÖNNQVIST, J. 2002. Efecto del tratamiento de oscuridad y salinidad en el rendimiento y calidad del agar de Gracilaria cornea (Rhodophyceae). Ciencias Marinas 28:289-296.

GONEN, Y., KIMMEL, E., TEL-OR, E. \& FRIEDLANDER, M. 1996. Intercellular assimilate translocation in Gracilaria cornea (Gracilariaceae, Rhodophyta). Hydrobiologia 326/327:421-428.

GRAHAM, J.M., GRAHAM, L.E. \& KRANZFELDER, J.A. 1985. Light, temperature and photoperiod as factors controlling reproduction in Ulothrix zonata (Ulvophyceae). Journal of Phycology 21:235-239.

GUIMARÃES, M. 2000. Aspectos fisiológicos de Gracilaria domingensis (Gracilariales, Rhodophyta): subsídios para a compreensão da manutenção do polimorfismo pigmentar. Tese de doutorado, Universidade de São Paulo, São Paulo.

GUIMARÃES, M., PLASTINO, E.M. \& OLIVEIRA, E.C. 1999. Life-history, reproduction, and growth of Gracilaria domingensis (Gracilariales, Rhodophyta) from Brazil. Botanica Marina 42:481-486.

GUIRY, M.D. 1984. Photoperiodic and temperature responses in the growth and tetrasporogenesis of Gigartina acicularis (Rhodophyta) from Ireland. Helgoländer Meeresuntersuchungen 38:335-347.

GUZMÁN-URIÓSTEGUI, A. \& ROBLEDO, D. 1999. Factors affecting sporulation of Gracilaria cornea (Gracilariales, Rhodophyta) carposporophytes from Yucatan, Mexico. Hydrobiologia 398/399:285-290. 
HOFFMANN, A.J. \& MALBRÁN, M.E. 1989. Temperature, photoperiod and light interactions on growth and fertility of Glossophora kunthii (Phaeophyta, Dictyotales) from central Chile. Journal of Phycology 25:129-133.

LEON, R.E.R. 1990. Experimental cultivation of an agarophyte alga: Gracilaria cornea in the northwest coast of Venezuela. In Cultivation of Seaweed in Latin America (E.C. Oliveira \& N. Kautzky, eds.). Workshop Universidade de São Paulo/ International Foundation for Science, São Sebastião, p.65-67.

LEVY, I. \& FRIEDLANDER, M. 1990. Strain selection in Gracilaria spp. - I. Growth, pigment, and carbohydrates characterization of strains of $G$. conferta and G. verrucosa (Rhodophyta, Gigartinales). Botanica Marina 33:339-345.

LIGNELL, A. \& PEDERSÉN, M. 1989. Agar composition as a function of morphology and growth rate. Studies on some morphological strains of Gracilaria secundata and Gracilaria verrucosa (Rhodophyta). Botanica Marina 32:219-227.

LOBBAN, C.S. \& HARISON, P.J. 1997. Seaweed ecology and physiology. Cambridge University Press, Cambridge.

MCHUGH, D.J. 1991. Worldwide distribution of commercial resources of seaweeds including Gelidium. Hydrobiologia 221:19-29.

MCLACHLAN, J. 1973. Growth media-marine. In Handbook of phycological methods. Culture methods and growth measurements (J.R. Stein, ed.). Cambridge University Press, Cambridge, p.25-21.

NAVARRO-ANGULO, L. \& ROBLEDO, D. 1999. Effects of nitrogen source, N:P ratio and N-pulse concentration and frequency on the growth of Gracilaria cornea (Gracilariales, Rhodophyta) in culture. Hydrobiologia 398/399:315-320.

ORDUÑA-ROJAS, J. \& ROBLEDO, D. 2002. Studies on the tropical agarophyte Gracilaria cornea J. Agardh (Rhodophyta, Gracilariales) from Yucatán, México. II. Biomass assessment and reproductive phenology. Botanica Marina 45:459-464.

ORDUÑA-ROJAS, J., ROBLEDO, D. \& DAWES, C.J. 2002. Studies on the tropical agarophyte Gracilaria cornea J. Agardh (Rhodophyta, Gracilariales) from Yucatán, México. I. Seasonal physiological and biochemical responses. Botanica Marina 45:453-458.

PAULA, E.J.P., ERBERT, C. \& PEREIRA, R.T.L. 2001. Growth rate of the carrageenophyte Kappaphycus alvarezii (Rhodophyta, Gigartinales) in vitro. Phycological Research 49:155-161.

PLASTINO, E.M. 1985. As espécies de Gracilaria (Rhodophyta, Gigartinales) da Praia Dura, Ubatuba, SP. - aspectos biológicos e fenologia. Dissertação de mestrado, Universidade de São Paulo, São Paulo.

PLASTINO, E.M. 2004. Diversidade intraespecífica em algas gracilarióides. Tese de Livre-Docência, Universidade de São Paulo, São Paulo.
PLASTINO, E.M. \& OLIVEIRA, E.C. 1988a. Deviation in the life-history of Gracilaria (Rhodophyta, Gigartinales), from Coquimbo, Chile, under different culture conditions. Hydrobiologia 164:67-74.

PLASTINO, E.M. \& OLIVEIRA, E.C. 1988b. Sterility barriers among species of Gracilaria (Rhodophyta, Gigartinales) from the São Paulo littoral, Brazil. British Phycological Journal 23:267-271.

PLASTINO, E.M. \& OLIVEIRA, E.C. 1990. Crossing experiments as an aid to the taxonomic recognition of the agarophyte alga Gracilaria (Rhodophyta, Gigartinales). In Cultivation of Seaweeds in Latin America (E.C. Oliveira \& N. Kautsky, eds.). Workshop Universidade de São Paulo/ International Foundation for Science, São Sebastião, p.127-133.

PLASTINO, E.M. \& OLIVEIRA, E.C. 2002. Gracilaria birdiae (Gracilariales, Rhodophyta), a new species from the tropical South American Atlantic with a terete frond and deep spermatangial conceptacles. Phycologia 41:389-396.

PLASTINO, E.M., GUIMARÃES, M., MATIOLI, S.R. \& OLIVEIRA, E.C. 1999. Codominant inheritance of polymorphic colour variants of Gracilaria domingensis (Gracilariales, Rhodophyta). Genetics and Molecular Biology 22:105-108.

PLASTINO, E.M., URSI, S. \& FUJII, M.T. 2004. Color inheritance, pigment characterization, and growth of a rare light green strain of Gracilaria birdiae (Gracilariales, Rhodophyta). Phycological Research 52:45-52.

RAMUS, J. \& VAN DER MEER, J.P. 1983. A physiological test of the theory of complementary chromatic adaptation. I. Color mutants of a red seaweed. Journal of Phycology 19: 86-91.

SINHA, R.P., KLISCH, M., GRÖNIGER, A. \& HÄDER, D.-P. 2000. Mycosporine-like amino acids in the marine red alga Gracilaria cornea - effects of UV and heat. Environmental and Experimental Botany 43:33-43.

VAN DER MEER, J.P. 1981. The inheritance of spontaneous pigment mutations in Chondrus crispus Stacklh. (Rhodophyceae). Proceedings of Natural Society Institute of Science 31:187-192.

VAN DER MEER, J.P. 1986. Genetic contributions to research on seaweeds. Progress in Phycological Research 4:1-38.

VAN DER MEER, J.P. 1990. Genetics. In Biology of the red algae (K. Cole \& R. Sheath, eds.). Cambridge University Press, Cambridge, p.103-122.

VAN DER MEER, J.P. \& BIRD, N.L. 1977. Genetics of Gracilaria sp. (Rhodophyceae, Gigartinales). I. Mendelian inheritance of two spontaneous green variants. Phycologia 16:159-161.

YOKOYA, N.S. \& OLIVEIRA, E.C. 1992. Temperature responses of economically important red algae and their potential for mariculture in Brazilian waters. Journal of Applied Phycology 4:339-345.

ZHANG, X. \& VAN DER MEER, J.P. 1988. A genetic study on Gracilaria sjoestedtii. Canadian Journal of Botany 66:2022-2026. 